\title{
FORENSIC ECONOMIC EXAMINATION AS AN INSTRUMENT FOR THE FORMATION OF PRINCIPLE TO ENSURE POSITIVE EFFECTS IN ECONOMY
}

\section{Homutenko O. V.}

The emergence of economic conflicts, just like any other conflicts, eventually requires the procedure of proving the presence or absence of certain elements that constituted the reason for their emergence. One of the ways of proving that in legal proceedings is a forensic economic examination. Based on the principles of economic synergy, the elimination, including, among other thing, of criminal interaction schemes, is a consequential development stage on the way of forming a solid economy of the region. Forensic economic examination is considered to be one of the modern forms of involvement in a set of measures to destroy undesirable economic systems by creating «chaos» as a precondition for creating something new. The information about conflict situations that is collected by conducting forensic economic examinations, among other sources, has a positive influence on the behavior of economic subjects with regard to their observance of norms regulating economic relations, and contributes to the observance of uniform operation rules and norms for all the enterprises in the region. This is a contribution to the formation of the principle that ensures positive synergy effects in the processes of modern regional development.

Keywords: classification of disputable economic situations, subject of forensic examination, positive effects.

\section{ЕКСПЕРТНА ПРАКТИКА: МЕТОДИЧНІ ПІДХОДИ ДО ВИРІШЕННЯ ЗАВДАНЬ ЕКОНОМІЧНИХ ДОСЛІДЖЕНЬ}

Д. Ю. Порошин, директор Дніпропетровського НДІСЕ,

Н. Ю. Семенова, завідувач сектору Дніпропетровського НДІСЕ

\section{ОСОБЛИВОСТІ БУХГАЛТЕРСЬКОГО ТА ПОДАТКОВОГО ОБЛІКІВ ОПЕРАЦІЙ ІЗ ПЕРЕВЕДЕННЯ БОРГУ}

Розглянуто особливості проведення судово-економічних досліджень із питань, пов'язаних з оподаткуванням податком на прибуток підприємств i податком на додану вартість операчій з переведення боргу.

Ключові слова: судово-економічна експертиза, переведення боргу, бухгалтерський облік, податковий облік.

Установлення відповідності чинному законодавству відображення в бухгалтерському й податковому обліках господарських операцій із переведення

(C) Порошин Д. Ю., Семенова Н. Ю., 2015 
боргу належить до завдань судово-економічної експертизи за експертною спеціальністю 11.1. Необхідність дослідження економічною експертизою питань, пов'язаних із оподаткуванням операцій із переведення боргу, виникає під час розслідування правоохоронними органами порушень податкового законодавства, а також оскарження в адміністративному порядку податкових повідомлень-рішень із цього питання.

Чинним законодавством передбачене оформлення переуступки боргу шляхом укладання договорів:

— при заміні кредитора в зобов'язанні (уступка права вимоги);

— при заміні боржника в зобов'язанні (переведення боргу).

Переведення боргу регулюється статтями 520-524 Цивільного кодексу України (далі - ЦК України). Боржник у зобов'язанні може бути замінений іншою особою (переведення боргу) лише за згодою кредитора. Наслідками переведення боргу є вибуття первинного боржника із зобов'язання, вступ до зобов'язання нового боржника та збереження у повному обсязі змісту зобов'язання при зміненні його суб'єктного складу.

Правила укладення угоди про переведення боргу встановлені ЦК України, а саме:

- згода кредитора (ст. 520);

- договір переведення боргу укладається або в тристоронньому порядку, або між первісним боржником і новим боржником за обов'язковою письмовою згодою кредитора;

- переведення боргу не має суперечити закону або договору.

Відповідно до вимог ЦК України угода про переведення боргу може бути оформлена таким чином:

- форма угоди така сама, як і при угоді, на підставі якої виникло зобов'язання, борг за яким був переданий новому боржнику (ст. 521, п. 1 ст. 513) (наприклад, якщо борг грунтується на операції, укладеній у письмовій формі, то й переведення боргу слід здійснювати в письмовій формі);

- необхідна державна реєстрація, якщо операція, унаслідок якої виникло зобов'язання, підлягала державній реєстрації (ст. 521, п. 2 ст. 513).

Статтею 522 ЦК України передбачено, що новий боржник має право пред'являти проти вимоги кредитора всі заперечення, які грунтуються на відносинах між кредитором і первісним боржником.

Правові наслідки, які можуть виникнути при зміні боржника в зобов'язанні, визначені в пп. 1, 2 ст. 523 ЦК України:

- поручительство й застава, установлені третьою особою, припиняються після заміни боржника, якщо поручитель або заставодавець не погодиться забезпечувати виконання зобов'язань новим боржником;

- застава, установлена первинним боржником, зберігається після заміни боржника, якщо інше не встановлене договором застави або законом.

У бухгалтерському обліку при відображенні операції з переведення боргу здійснюється зміна в складі зобов'язань. Зокрема, це відбувається при зміні сторони в зобов'язанні, яке змінюється (дебітор), і заборгованості, яка передається (кредиторська). 
Бухгалтерський облік операцій $з$ переведення боргу здійснюється відповідно до вимог Положення (стандарту) бухгалтерського обліку 10 «Дебіторська заборгованість» (далі - ПСБО 10), Положення (стандарту) бухгалтерського обліку 11 «Зобов’язання» (далі - ПСБО 11) ${ }^{2}$ та Інструкції про застосування Плану рахунків бухгалтерського обліку активів, капіталу, зобов'язань і господарських операцій підприємств і організацій (далі - Iнструкція № 291)³.

Наявність заборгованості між старим і новим боржниками на момент здійснення операції з переведення боргу впливає на відображення таких операцій у бухгалтерському обліку таким чином. Якщо заборгованість існує (перший боржник є кредитором другого боржника за іншою операцією, ніж переведення боргу), то операція з переведення боргу відображається в обліку обох сторін, як залік їх кредиторської й дебіторської заборгованостей. Якщо ж заборгованості не існує, то в першого боржника при переведенні боргу погашається зобов'язання перед кредитором і нараховується зобов'язання перед новим боржником, а в другого боржника при компенсації переведеного боргу нараховується зобов'язання перед кредитором з одночасним відображенням дебіторської заборгованості першого боржника. Суму компенсації вартості переведеного боргу перший і другий боржники враховують на загальних підставах залежно від способу такої компенсації.

Особливості оподаткування операцій з уступки права вимоги викладені в п. 153.5 Податкового кодексу України (далі - ПК України).

Чітких норм щодо відображення в податковому обліку операцій із переведення боргу ПК України не містить. Об'єктом оподаткування з податку на додану вартість та податку на прибуток $\epsilon$, відповідно, постачання послуг (підп. 14.1.185) та постачання товарів (підп. 14.1.191), продаж товарів (підп. 14.1.202) і продаж результатів робіт (послуг) (підп. 14.1.203).

Підпунктом 134.1.1 п. 134.1 ст. 134 ПК України визначено, що об’єктом оподаткування податком на прибуток $є$ прибуток із джерелом походження з України та за ії межами, який визначається шляхом зменшення суми доходів звітного періоду, визначених згідно зі статтями 135-137 цього Кодексу, на собівартість реалізованих товарів, виконаних робіт, наданих послуг і суму інших витрат звітного податкового періоду, визначених згідно зі статтями 138-143 цього Кодексу, з урахуванням правил, установлених статтею 152 цього Кодексу.

1 Див.: Положення (стандарту) бухгалтерського обліку 10 «Дебіторська заборгованість» : наказ М-ва фінансів України від 08.10.1999 № 237 (зі змінами та допов.) [Електронний ресурс]. — Режим доступу : http://zakon1.rada.gov.ua/laws/ show/z0725-99.

2 Див.: Положення (стандарту) бухгалтерського обліку 11 «Зобов’язання» : наказ М-ва фінансів України від 31.01.2000 № 20 (зі змінами та допов.) [Електронний pecypc]. - Режим доступу : http://zakon1.rada.gov.ua/laws/show/z0085-00.

Див.: Інструкція про застосування Плану рахунків бухгалтерського обліку активів, капіталу, зобов'язань і господарських операцій підприємств і організацій : наказ М-ва фінансів України від 30.11.1999 № 291 (зі змінами та допов.) [Електронний ресурс]. — Режим доступу : http://zakon2.rada.gov.ua/laws/show/z0893-99. 
Пунктом 185.1 ст. 185 ПК України визначено, що об’єктом оподаткування податком на додану вартість є:

a) постачання товарів, місце постачання яких розташоване на митній території України, відповідно до ст. 186 цього Кодексу, у тому числі операції 3 передачі права власності на об'єкти застави позичальнику (кредитору), на товари, що передаються на умовах товарного кредиту, а також із передачі об'єкта фінансового лізингу в користування лізингоотримувачу/орендарю;

б) постачання послуг, місце постачання яких розташоване на митній території України, відповідно до ст. 186 цього Кодексу;

в) увезення товарів на митну територію України;

г) вивезення товарів за межі митної території України;

е) постачання послуг із міжнародних перевезень пасажирів і багажу та вантажів залізничним, автомобільним, морським і річковим та авіаційним транспортом.

Операції з переведення боргу не є об' єктом оподаткування податком на прибуток і податком на додану вартість, оскільки:

- такі господарські операції не можуть кваліфікуватися як отримання доходу та не є торгівлею борговими зобов'язаннями;

- передача кредиторської заборгованості першого боржника другому є зобов'язанням, а не товаром, роботами або послугами;

- такі господарські операції не відповідають жодному визначенню операцій із постачання товарів, послуг або факторингу.

У результаті аналізу норм ПК України встановлено, що об'єкт оподаткування господарських операцій із переведення боргу може виникнути в разі, коли в сторін з'явиться дохід. Наприклад, у нового боржника - коли йому передбачається винагорода. Оподаткування таких доходів (інших доходів) регламентується нормами п. 135.5.

Розглянемо ситуачію на декількох прикладах.

1. Переведення грошового боргу, коли між 1-м боржником і 2-м боржником існує грошова заборгованість за іншими господарськими операціями (рис. 1).

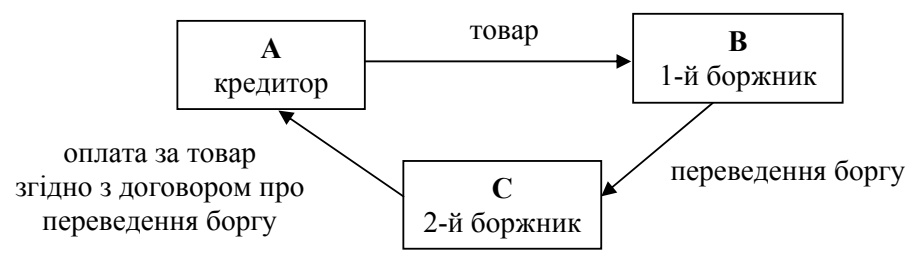

Рис. 1. Схема № 1.

Пояснення до схеми № 1:

- за обліковими даними в підприємства С існує кредиторська заборгованість перед підприємством В за виконані роботи; 
— підприємство А відвантажило товар підприємству В за договором купівлі-продажу. Податкові наслідки: у підприємства А - податкові зобов'язання з ПДВ, за податком на прибуток виникнуть доходи від реалізації товару та витрати на суму собівартості реалізованих товарів; у підприємства В - податковий кредит з ПДВ, за податком на прибуток податкові наслідки на цій стадії відсутні;

- укладений тристоронній договір із переведення боргу між В (1-й боржник), C (2-й боржник) і А (кредитор) про переведення боргу з В на С, яким передбачено залік заборгованостей між В та С і перерахування грошових коштів від С до А за поставлений В товар. Підприємство С оплатило підприємству А згідно з договором про переведення боргу. Податкові наслідки взаємозаліку дебіторської й кредиторської заборгованостей підприємств В та С, а також перерахування підприємством С грошових коштів на виконання договору про переведення боргу підприємству А відсутні.

2. Переведення грошового боргу, коли заборгованості між усіма учасниками не існує (рис. 2).

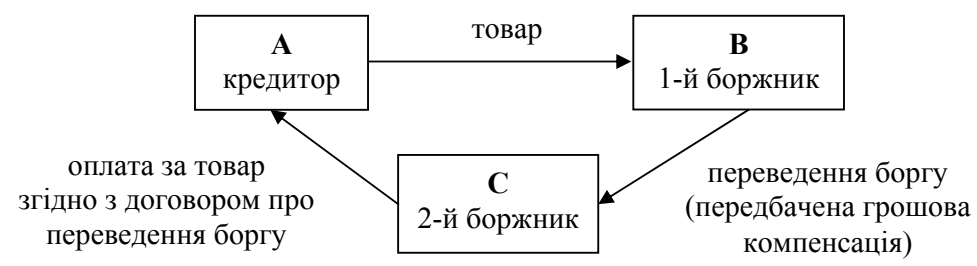

Рис. 2. Схема № 2 .

Пояснення до схеми № 2:

- між учасниками тристороннього договору з переведення боргу будьяка заборгованість за іншими господарськими операціями відсутня;

- підприємство А відвантажило товар підприємству В за договором купівлі - продажу. Податкові наслідки: у підприємства А - податкові зобов'язання з ПДВ, за податком на прибуток виникнуть доходи від реалізації товару та витрати на суму собівартості реалізованих товарів; у підприємства В - податковий кредит із ПДВ, за податком на прибуток податкові наслідки на цій стадії відсутні;

- укладений тристоронній договір із переведення боргу між В (1-й боржник), C (2-й боржник) і А (кредитор) про переведення боргу з В на С, перерахування грошових коштів від С до А за поставлений В товар, передбачена 100 \% грошова компенсація підприємству С від підприємства В у встановлені договором строки. Підприємство С оплатило підприємству А згідно з договором про переведення боргу. Податкові наслідки перерахування підприємством С грошових коштів на виконання договору про переведення боргу підприємству А та компенсація від підприємства В підприємству С відсутні. 


\section{3. Переведення боргу за кредитним договором (рис. 3).}

Відповідно до підп. 14.1.258 п. 14.1 ст. 14 ПК України фінансовий кредит це кошти, які надаються банком-резидентом або нерезидентом, що кваліфікується як банківська установа згідно із законодавством країни перебування нерезидента, або резидентами і нерезидентами, які мають згідно з відповідним законодавством статус небанківських фінансових установ, а також іноземною державою або її офіційними агентствами, міжнародними фінансовими організаціями та іншими кредиторами - нерезидентами юридичній чи фізичній особі на визначений строк для цільового використання та під процент.

Проценти - дохід, який сплачується (нараховується) позичальником на користь кредитора як плата за використання залучених на визначений або невизначений строк коштів або майна (підп. 14.1.206 п. 14.1 ст. 14 ПК України).

Господарська діяльність - це діяльність особи, що пов'язана з виробництвом (виготовленням) i/aбо реалізацією товарів, виконанням робіт, наданням послуг, спрямована на отримання доходу та проводиться такою особою самостійно й/або через свої відокремлені підрозділи, а також через будь-яку іншу особу, що діє на користь першої особи, зокрема за договорами комісії, доручення та агентськими договорами (підп. 14.1.36 п. 14.1 ст. 14 ПК України).

До складу витрат уключаються будь-які витрати, пов'язані з нарахуванням процентів за борговими зобов'язаннями (у тому числі, за будь-якими кредитами, позиками, депозитами, крім фінансових витрат), уключених до собівартості кваліфікаційних активів відповідно до положень (стандартів) бухгалтерського обліку протягом звітного періоду, якщо такі нарахування здійснюються у зв'язку з провадженням господарської діяльності платника податку (п. 141.1 ст. 141 ПК України).

Не включаються в дохід і не підлягають оподаткуванню кошти або майно, залучені платником податку у зв'язку з отриманням платником податку основної суми фінансових кредитів, позик від інших осіб - кредиторів, а також поверненням основної суми фінансових кредитів, позик, наданих платником податку іншим особам - дебіторам (підп. 153.4.1 п. 153.4 ст. 153 ПК України).

Не включаються до витрат кошти або майно, надані платником податку у зв'язку з поверненням платником податку основної суми кредиту, позики, процентної позики, а також із наданням основної суми кредиту, позики іншим особам - дебіторам. Термін «основна сума» означає суму наданого кредиту, позики або депозиту (строкових, довірчих рахунків) без урахування процентів, фіксованих виплат, премій тощо (підп. 153.4.2 п. 153.4 ст. 153 ПК України).

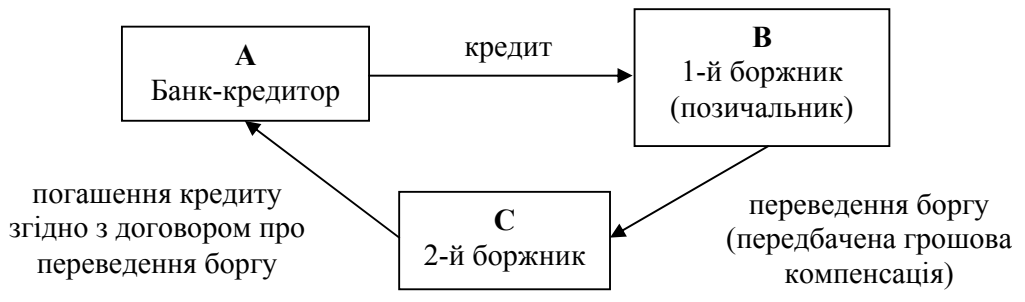

Рис. 3. Схема № 3. 
Пояснення до схеми № 3:

- між учасниками тристороннього договору з переведення боргу будьяка заборгованість за іншими господарськими операціями відсутня;

- банк А надав фінансовий кредит підприємству В за кредитним договором. Податкові наслідки за податком на прибуток та ПДВ на цій стадії відсутні, оскільки надання та отримання основної суми кредиту не відображається в складі доходів і витрат, а також не є об'єктом оподаткування ПДВ. Об'єктом оподаткування податком на прибуток будуть нараховані позичальнику В відсотки за кредитом відповідно до вимог п. 141.1 ст. 141 ПК України;

- укладений тристоронній договір із переведення боргу між В (1-й боржник-позичальник), C (2-й боржник) і А (банк-кредитор) про переведення боргу з В на С, підприємство С здійснює погашення кредиту згідно з договором про переведення боргу, передбачена 100 \% грошова компенсація підприємству С від позичальника В у встановлені договором строки. Підприємство С здійснило погашення кредиту банку-кредитору А згідно з договором про переведення боргу. Податкові наслідки перерахування підприємством С грошових коштів на виконання договору про переведення боргу підприємству А та компенсація від підприємства В підприємству С відсутні.

4. Переведення товарного боргу, коли між 1-м боржником і 2-м боржником існує товарна заборгованість (рис. 4).

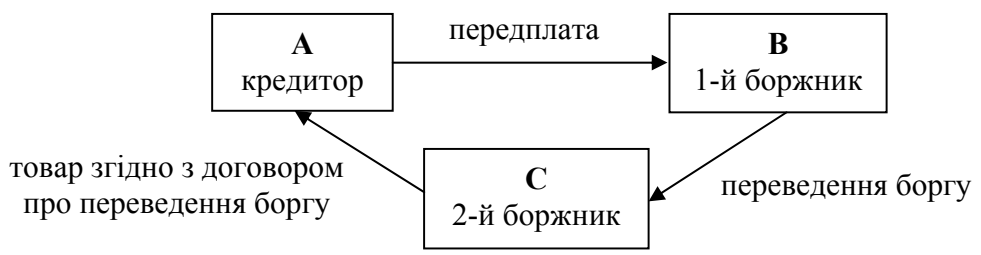

Рис. 4. Схема № 4

Пояснення до схеми № 4:

- за обліковими даними в підприємства $\mathrm{C}$ існує товарна кредиторська заборгованість перед підприємством В за іншими господарськими операціями (В здійснило передплату за товар підприємству С, а підприємство С товар не відвантажило);

- підприємство А здійснило передплату за товар підприємству В за договором купівлі-продажу. Податкові наслідки: у підприємства А - податковий кредит із ПДВ, за податком на прибуток податкові наслідки на цій стадії відсутні; у підприємства В - податкові зобов'язання з ПДВ, за податком на прибуток податкові наслідки на цій стадії відсутні;

- укладений тристоронній договір із переведення боргу між В (1-й боржник), С (2-й боржник) і А (кредитор) про переведення боргу з В на С, яким передбачено залік заборгованостей між В та С і відвантаження товару від С до А. Підприємство С відвантажило товар підприємству А згідно з до- 
говором про переведення боргу. Податкові наслідки взаємозаліку дебіторської й кредиторської заборгованостей підприємств В та С, а також відвантаження товару підприємством С підприємству А на виконання договору про переведення боргу відсутні.

5. Переведення товарного боргу, коли заборгованості між усіма учасниками не існує (рис. 5).

Відповідно до вимог п. 192.1 ст. 192 ПК України, якщо після постачання товарів/послуг здійснюється будь-яка зміна суми компенсації їх вартості, уключаючи наступний за постачанням перегляд цін, перерахунок у випадках повернення товарів/послуг особі, яка їх надала, або при поверненні постачальником суми попередньої оплати товарів/послуг, суми податкових зобов'язань і податкового кредиту постачальника та отримувача підлягають відповідному коригуванню.

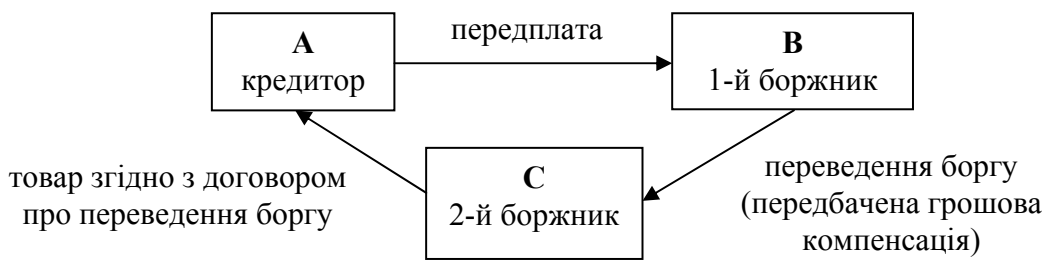

Рис. 5. Схема № 5

Пояснення до схеми № 5:

- між учасниками тристороннього договору з переведення боргу будьяка заборгованість за іншими господарськими операціями відсутня;

- підприємство А здійснило передплату за товар підприємству В за договором купівлі-продажу. Податкові наслідки: у підприємства А - податковий кредит із ПДВ, за податком на прибуток податкові наслідки на цій стадії відсутні; у підприємства В - податкові зобов'язання з ПДВ, за податком на прибуток податкові наслідки на цій стадії також відсутні;

- укладений тристоронній договір із переведення боргу між В (1-й боржник), C (2-й боржник) і А (кредитор) про переведення боргу з В на С, яким передбачена 100 \% грошова компенсація від В до С та відвантаження товару від С до А. Підприємство С відвантажило товар підприємству А згідно 3 договором про переведення боргу. Податкові наслідки: здійснюється коригування податкових зобов'язань і податкового кредиту з ПДВ (складається розрахунок коригування кількісних та вартісних показників) підприємств В й А, які були задекларовані по першій події - передплаті за товар, на підставі вимог п. 192.1 ст. 192, п. 187.1 ст. 187, пП. 198.1, 198.2 ст. 198 ПК України. Таке коригування здійснюється, оскільки при укладанні договору про переведення боргу зобов'язання з поставки товару первісним боржником перед покупцем припиняються, право на віднесення сум податку до податкових зобов'язань та податкового кредиту виникає у зв'язку з продажем і придбанням товарів (робіт, послуг). При здійсненні операції з відвантажен- 
ня товару підприємством С підприємству А за договором переведення боргу, С виписує податкову накладну на адресу А, оскільки податкова накладна видається платником податку, який здійснює операції з постачання товарів/ послуг (п. 201.10 ст. 201 ПК України), крім того, підприємство В компенсує С вартість такого товару. Щодо податкових наслідків із податку на прибуток, то при відвантаженні товару в підприємства С виникають доходи від реалізації товару та витрати в розмірі собівартості реалізованих товарів, у підприємств А й В податкові наслідки з податку на прибуток відсутні.

Обсяг документів, необхідних для дослідження, визначається конкретними обставинами справи та питаннями, які поставлені перед експертом. При проведенні дослідження з питань оподаткування податком на прибуток і податком на додану вартість експерт застосовує методи експертного дослідження: документальної перевірки та зіставлення із застосуванням методики «Методи, способи та прийоми, які використовуються при проведенні судовоекономічних експертиз» (реєстраційний код 11.0.08). При цьому подані документи перевіряються за формою, змістом і по суті відображених у них господарських операцій, зокрема на відповідність вимогам ст. 9 Закону України «Про бухгалтерський облік та фінансову звітність в Україні» ${ }^{1}$ й «Положення про документальне забезпечення записів у бухгалтерському обліку»². Також перевіряється відповідність записів у документах вимогам нормативних актів.

Отже, під час проведення дослідження господарських операцій з переведення боргу експертом досліджуються дані первинних документів, які пов'язані зі здійсненням операції, перевіряється відповідність обов'язкових реквізитів вимогам нормативних актів. Дані первинних документів, договірної документації зіставляються з даними облікових регістрів і, відповідно, з даними податкового обліку (декларацій з податку на прибуток підприємства та податку на додану вартість 3 додатками). Експерту слід пам’ятати, що проведення ревізійних дій (визначення експертами-економістами будь-яких економічних показників без попереднього проведення документальних перевірок фінансово-господарської діяльності суб'єктом контролю) не належить до завдань економічної експертизи. Тому разом з об'єктами дослідження до експертної установи надаються акти документальних перевірок.

\section{ОСОБЕННОСТИ БУХГАЛТЕРСКОГО И НАЛОГОВОГО УЧЕТА ОПЕРАЦИЙ ПО ПЕРЕВОДУ ДОЛГА}

\section{Порошин Д. Ю., Семенова Н. Ю.}

Рассмотрены особенности производства судебно-экономических исследований по вопросам, связанным с налогообложением налогом на при-

1 Див.: Про бухгалтерський облік та фінансову звітність в Україні : Закон України від 16.07.1999 № 996-XIV (зі змінами та допов.) [Електронний ресурс]. — Режим доступу : http://zakon4.rada.gov.ua/laws/show/996-14.

Див.: Про затвердження Положення про документальне забезпечення записів у бухгалтерському обліку : наказ М-ва фінансів України від 24.05.1995 № 88 (зі змінами та допов.) [Електронний ресурс]. — Режим доступу : http://zakon4.rada.gov.ua/ laws/show/z0168-95. 
быль предприятий и налогом на добавленную стоимость операциий по переводу долга.

Ключевые слова: судебно-экономическая экспертиза, перевод долга, бухгалтерский учет, налоговый учет.

\section{PECULIARITIES OF FINANCIAL AND TAX ACCOUNTING OF TRANSACTIONS ON DEBT CONVERSION}

\section{Poroshin D. Yu., Semenova N. Yu.}

The article deals with peculiarities of conducting forensic economic studies connected with collecting income tax and value added tax as well as the order for recording debt conversion in financial accounting. It discusses methods that are used while conducting the studies, lists the relevant articles of normative acts that regulate the order of recording debt conversion transactions in financial accounting. It also considers a number of possible situations for debt conversion transactions, the order of recording them in financial accounting and tax consequences of these transactions. Having analyzed the requirements of the tax legislation, the article claims that debt conversion transactions constitute an object exempt of income tax and vale added tax because: such transactions cannot be classified as obtaining income and do not constitute trade in debt obligations; the transfer of credit debt of one debtor to another is still a liability and not a commodity (work or service); such transactions do not conform with any definition of transactions for the supply of goods, services or factoring.

Keywords: forensic economic examination, debt conversion, financial accounting, tax accounting.

П. О. Івахненко, судовий експерт Харківського НДІСЕ

\section{ПРОБЛЕМНІ АСПЕКТИ ЩОДО ВИРІШЕННЯ ПИТАНЬ ПРИ ПРОВЕДЕННІ СУДОВИХ ЕКОНОМІЧНИХ ЕКСПЕРТИЗ ДОКУМЕНТІВ ФІНАНСОВО-КРЕДИТНИХ ОПЕРАЦІЙ}

Виходячи з експертної практики, розглянуто основні питання, що ставляться на вирішення експертизи документів фінансово-кредитних операцій. Наведено пропозииї щодо змін у науково-методичних рекомендаціях з питань підготовки та призначення судових експертиз і експертних досліджень.

Ключові слова: фінансово-кредитні операції, кредитування, сукупна вартість кредиту, реальна відсоткова ставка, змінювана відсоткова ставка, вартість кредитних ресурсів.

Зважаючи на значне збільшення кількості призначених експертиз, пов'язаних із дослідженням документів фінансово-кредитних операцій, що викликане великим обсягом виданих кредитів на початку 2000-х рр. і по-

(C) Івахненко П. О., 2015 